\title{
A new species and synonymy in Atrypanius Bates (Coleoptera, Cerambycidae, Lamiinae) from the Brazilian Amazon forest
}

\author{
Antonio Santos-Silva' \\ 1 Universidade de São Paulo (USP), Museu de Zoologia (MZUSP). São Paulo, SP, Brasil. \\ ORCID: http://orcid.org/0000-0001-7128-1418. E-mail: toncriss@uol.com.br
}

\begin{abstract}
Atrypanius jauffreti sp. nov. is described from Brazil (Pará). Nyssodrys grisella Bates, 1864 (currently, Atrypanius grisellus) is synonymized with Lepturges lineatocollis Bates, 1863 (currently, Atrypanius lineatocollis), and the species is recorded for the Brazilian states of Rondônia and Mato Grosso.
\end{abstract}

Keywords. Acanthocinini; South America; Taxonomy.

\section{INTRODUCTION}

The specimens of the new species were collected by the French biologist Pierre Edward Jauffret, who defended the preservation of the Amazon and was murdered in 2009 in Santo Antônio do Tauá (Brazil, Pará). He bought land in Santo Antônio do Tauá, where for more than 40 years kept the entire area conserved for research, often facing conflicts alone against the clearing of the forest and the invasion of one of the few conserved areas in the northeast Pará. Unfortunately, the Brazilian state of Pará is one of the dangerous places in the country for those who defend the preservation. This can be confirmed with a simple search in newspapers and with information provided by the Comissão Pastoral da Terra (Pastoral Land Commission), an organ of the National Conference of Bishops of Brazil (Brazilian Roman Catholic Church). Most striking is the fact that the vast majority of cases of violence and murder remain only as statistics, with no punishment for those found guilty.

Atrypanius Bates, 1864 is exclusively American, occurring from eastern United States of America to southern South America, with 27 known species. Of these, 19 are recorded from Brazil, and 14 in the Brazilian Amazon. With the description of a new species and the synonymy of another, both from the Amazon rainforest, these numbers remain unchanged.

\section{MATERIAL AND METHODS}

Photographs were taken in the MZSP with a Canon EOS Rebel T3i DSLR camera, Canon MP-E
$65 \mathrm{~mm}$ f/2.8 1-5X macro lens, controlled by Zerene Stacker AutoMontage software. Measurements were taken in " $\mathrm{mm}$ " using measuring ocular Hensoldt/Wetzlar - Mess 10 in the Leica MZ6 stereomicroscope, also used in the study of the specimens.

The acronyms used in the text correspond to the Museu de Zoologia, Universidade de São Paulo, São Paulo, Brazil (MZSP), and Muséum national d'Histoire naturelle (MNHN).

\section{RESULTS}

Atrypanius jauffreti sp. nov.

(Figs. 1A-1D)

Description: Holotype male: Head mostly dark brown; gulamentum dark reddish brown; scape mostly testaceous, with posterior half of dorsal surface and posterior quarter brown; pedicel testaceous except brown apical area; antennomeres III-VI yellowish brown except dark brown apex; antennomeres VII-VIII dark yellowish brown except dark brown apex; antennomeres IX-XI brown. Scutellum distinctly darker than elytra. Prothorax and elytra dark brown, except reddish brown anterior margin and posterior eight of pronotum. Mesoventrite dark brown anteriorly, orangish brown close to mesocoxal cavities; mesoventral process mostly orangish brown; mesanepisternum, mesepimeron, and metanepisternum dark brown; metaventrite mostly orangish brown except large dark brown macula on center of posterior 3/4. Legs mostly brown; metafemora dark red- 
dish brown on peduncle, brownish on remaining surface. Abdominal ventrites mostly orangish brown.

Head: Frons slightly convex, minutely, densely punctate; with pale yellowish-brown pubescence partially obscuring integument, yellower close to eyes and pale yellow centrally (pale yellow pubescence appearing whiter depending on the intensity of the light); with one somewhat long, arched black seta on each side close to inferior margin of eyes. Area between antennal tubercles with pale yellow pubescence obscuring integument centrally, pale yellowish brown, partially obscuring integument

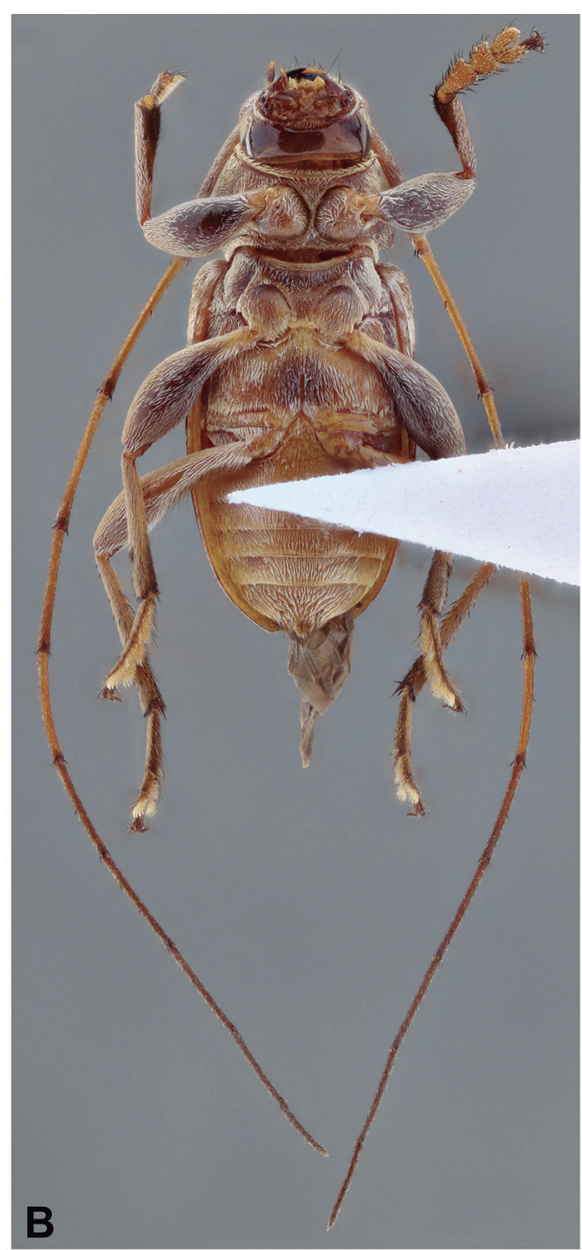

A
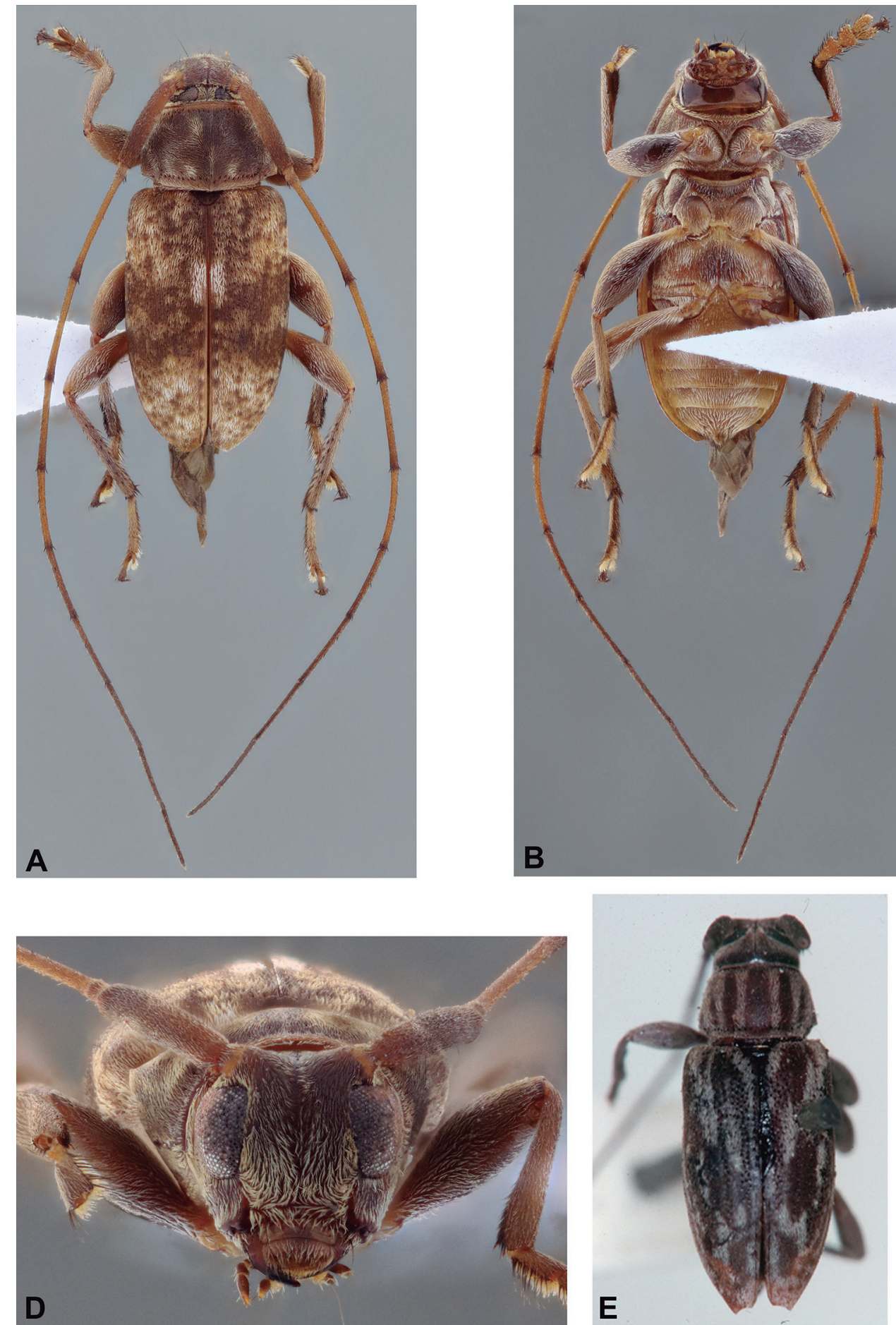

laterally, except glabrous median groove and transverse sulcus between antennal tubercles and upper eye lobes; transverse sulcus and median groove forming a cross; remaining surface of vertex with pale yellow pubescence obscuring integument, except glabrous median groove. Area behind eyes with pale yellowish-brown pubescence obscuring integument. Genae 0.55 times length of lower eye lobes; with pale yellowish-brown pubescence not obscuring integument, except dense narrow band close to eye. Wide central area of postclypeus with bristly pale yellowish-brown pubescence not obscuring integument, with one long, erect, black seta on each side.
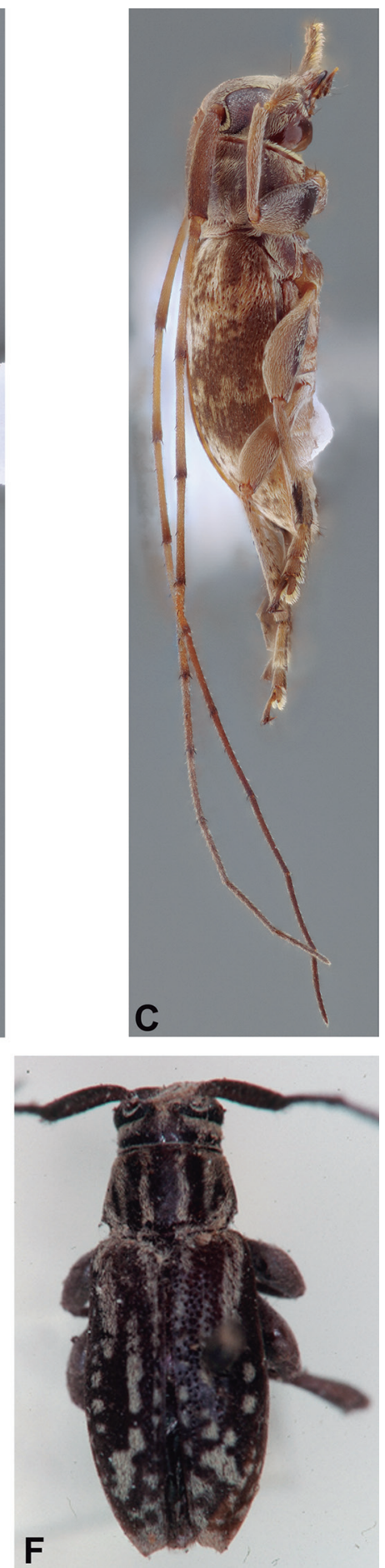

Figure 1. (A-D) Atrypanius jauffreti sp. nov., holotype male: (A) Dorsal habitus; (B) Ventral habitus; (C) Lateral habitus; (D) Head, frontal view. (E-F) Atrypanius lineatocollis (Bates, 1863), dorsal habitus: (E) Lepturges lineatocollis, holotype male; (F) Nyssodrys grisella Bates, 1864, holotype male. 
Labrum slightly convex, coplanar with anteclypeus at posterior 3/4, inclined at anterior quarter; with minute yellowish-white pubescence not obscuring integument on coplanar area, and long, erect, sparse black setae directed forward interspersed; anterior margin with short fringe of golden setae. Gulamentum smooth, glabrous, except narrow anterior area depressed, with pale yellowish-brown pubescence not obscuring integument, and a few erect dark setae near anterior margin. Distance between upper eye lobes 0.17 times distance between outer margins of eyes; in frontal view, distance between lower eye lobes superiorly 0.48 times distance between outer margins of eyes (0.56 times inferiorly). Antennae 3.1 times elytral length, reaching elytral apex at posterior quarter of antennomere $\mathrm{V}$; with yellowish-white pubescence not obscuring integument; ventral apex of pedicel with short, thick black setae; antennomeres with short, erect, sparse black setae, slightly more conspicuous apically on III-X, and short, erect, sparse white setae throughout. Antennal formula based on length of antennomere III: scape $=0.91$; pedicel $=0.13 ; \mathrm{IV}=0.93 ; \mathrm{V}=0.78$; $\mathrm{VI}=0.71 ; \mathrm{VII}=0.70 ; \mathrm{VIII}=0.71 ; \mathrm{IX}=0.70 ; \mathrm{X}=0.65 ; \mathrm{XI}=0.60$.

Thorax: Prothorax distinctly transverse; sides slightly rounded, gradually divergent from anterolateral angles to lateral tubercle, then abruptly narrowed; lateral tubercles somewhat large, with its apex acute, slightly directed backward, placed near posterolateral angles. Pronotum finely, abundantly punctate except posterior eight with sparser punctures; area near anterior and posterior margins with row of coarse punctures (slightly coarser, not surpassing lateral tubercles posteriorly); with abundant pale yellowish-brown pubescence not obscuring integument, except two pale yellow pubescent bands (appearing whiter depending on the intensity of the light) on each side of middle (subfused after middle), and pubescence of same color laterally; with a few long, erect black setae behind lateral tubercles of prothorax. Sides of prothorax minutely, densely punctate; with pale yellowish-brown pubescence partially obscuring integument. Ventral surface of thorax with abundant pale yellowish-brown pubescence not obscuring integument, denser laterally. Narrowest area of prosternal process 0.09 times procoxal width; narrowest area of mesoventral process 0.42 times mesocoxal width. Scutellum with brownish pubescence not obscuring integument. Elytra: Basal and apical thirds with abundant pale yellowish-brown pubescence (appearing more yellowish-white depending on light intensity) with irregular areas with slightly conspicuous brownish pubescence interspersed; anterior third with white pubescent macula on each side of scutellum; posterior half with abundant white pubescent macula interspersed; central third mostly with slightly conspicuous brownish pubescence, with irregular pale yellowish-brown pubescent macula interspersed; area close to suture on central third with dense white pubescent macula (together on both elytra forming subcircular macula); apex obliquely truncate. Legs: With abundant yellowish-white pubescence not obscuring integument (appearing whiter depending on light intensity), except ventral surface of tibiae with yellowish-brown pubescence (basal half of protibiae, apical third on meso- and metatibiae), and dorsal sulcus of mesotibiae with dark brown pubescence; ventral surface of meso- and metatibiae with long, oblique black setae interspersed, more abundant on metatibiae; dorsal and lateral surfaces of meso- and metatibiae with short, sparse, thick black setae interspersed, distinctly more abundant on metatibiae; tarsomeres I-III with long dark setae laterally.

Abdomen: Ventrites with abundant yellowish-white pubescence not obscuring integument; apical area of ventrite $\mathrm{V}$ with long black setae directed backward.

Variation: Pale yellow pubescence on pronotum forming 8-shaped macula on each side of middle.

Dimensions (mm) (Holotype/paratypes): Total length, 4.95/4.75-6.20; prothoracic length, 1.05/1.00-1.30; anterior prothoracic width, 1.30/1.20-1.60; posterior prothoracic width, 1.35/1.25-1.70; maximum prothoracic width, 1.70/1.60-2.05; humeral width, 1.90/1.85-2.35; elytral length, 3.30/3.05-4.20.

Type material: Holotype male from BRAZIL, Pará: Ulianópolis, Fazenda São Lucas, 01.I.2002, Jauffret leg. (MZSP). Paratypes - $1 \sigma^{\prime \prime}$, same data as holotype except for 31.XII.2001, ex larva from Ficus sp. (MZSP); $1 \sigma^{2}$, same data as holotype except for 06.I.2002 (MZSP); $1 \sigma^{\prime \prime}$, same data as holotype except for 08.I.2002, ex larva from Ficus sp. (MZSP).

Etymology: The new species is named in honor of the late Pierre Edward Jauffret.

Remarks: Atrypanius jauffreti sp. nov. is similar to $A$. irrorellus Bates, 1885, but differs especially by the elytral pubescent pattern formed by two areas with dense pubescence, and with distinct white central pubescent macula (with irregular small pubescent spots and without white pubescent macula in A. irrorellus). The other species of the genus cannot be confused with the new species, either by the pattern of pubescence distribution and/or general body shape.

\section{Atrypanius lineatocollis (Bates, 1863) (Figs. 1E-1F)}

Lepturges lineatocollis Bates, 1863: 373.

Lepturgus lineatocollis; Gemminger, 1873: 3157 (cat.). Nyssodrys lineatocollis; Bates, 1885: 412; Aurivillius, 1923: 425 (cat.); Blackwelder, 1946: 618 (checklist). Nyssodrystes lineatocollis; Gilmour, 1965: 599 (cat.). Nyssodrysina lineatocollis; Monné, 1985: 547; Monné \& Giesbert, 1994: 257 (checklist); Monné, 1995: 135 (cat.); Ødegaard, 2004: 86 (hosts); Monné, 2005: 101 (cat.); Wappes et al., 2006: 36 (distr.); Morvan \& Roguet, 2013: 8 (distr.). 
Atrypanius lineatocollis; Monné et al., 2020: 25; Monné, 2021: 29 (cat.).

Nyssodrys grisella Bates, 1864: 154; Gemminger, 1873: 3161 (cat.); Aurivillius, 1923: 425 (cat.); Blackwelder, 1946: 618 (checklist). Syn. nov.

Nyssodrystes grisella; Gilmour, 1965: 599 (cat.).

Nyssodrysina grisella; Monné, 1985: 547; Monné \& Giesbert, 1994: 257 (checklist); Monné, 1995: 134 (cat.); 2005: 100 (cat.).

Atrypanius grisellus; Monné et al., 2020: 24; Monné, 2021: 27 (cat.).

Bates (1863) described the pronotum of Lepturges lineatocollis (Fig. 1E) as "grey, with five black vittae, the middle one much the broadest." Later, Bates (1864) described the pronotum of Nyssodrys grisella (Fig. 1F) as having the "surface tawny grey; disk with three dark brown vittae." Apparently, when describing N. grisella, Bates (1864) disregarded the two outermost bands of the pronotum, which were considered in the description of L. lineatocollis. Examination of photographs of the holotype of both species shows that the number and position of the dark bands of the pronotum are identical in both species. Furthermore, the elytral pubescence is nearly identical on basal half, being slightly different only on posterior half. This difference appears to be only intraspecific variation. As there is no other differences (e.g., body shape, prothoracic shape, elytral sculpturing, elytral shape, etc.), Nyssodrys grisella is synonymized with Lepturges lineatocollis.

Material examined: BRAZIL, Rondônia (new state record): Porto Velho, $10^{\circ}$, VII.1960, Forattini leg. (MZSP). Mato Grosso (new state record): $12^{\circ} 31^{\prime} \mathrm{S} 51^{\circ} 46^{\prime} \mathrm{W}$ [Currently, Bom Jesus do Araguaia], $10^{\prime \prime}$, 05.XII.1968, RS/RGS Exp. Brazil [Royal Society/Royal Geographical Society - known as "Expedição Mato Grosso"], R.A. Beaver leg. (MZSP). Specimens examined through photographs: BRAZIL, Amazonas: Ega (currently, Tefé), holotype male of Nyssodrys grisella, H.W. Bates leg. (MNHN). Pará: Santarém, holotype male of Lepturges lineatocollis, H.W. Bates leg. (MNHN).

Geographical distribution: Panama, Ecuador, French Guiana, Brazil (Amazonas, Pará, Mato Grosso), Bolivia (Santa Cruz).

\section{ACKNOWLEDGMENTS}

I thank the Taxonline Project (Projeto Taxonline - Rede Paranaense de Coleções Biológicas) for sending some slides used in this work, which belong to the Coleção de Imagens de material-tipo J.S. Moure (CITIMOURE) of the entomological collection Pe. J.S. (DZUP).

\section{REFERENCES}

Aurivillius, C. 1923. Cerambycidae: Lamiinae II. Coleopterorum Catalogus, pars 74, Cerambycidae: Lamiinae. Berlin, W. Junk. p. 323-704.

Bates, H.W. 1863 Contributions to an insect fauna of the Amazon Valley. Coleoptera: Longicornes. The Annals and Magazine of Natural History, 12(3): 367-381.

Bates, H.W. 1864. Contributions to an insect fauna of the Amazon Valley. Coleoptera: Longicornes. The Annals and Magazine of Natural History, 13(3): 144-164.

Bates, H.W. 1885. Supplement. In: Godman, F.D. \& Salvin, 0. (Eds.). Biologia Centrali-Americana. Vol. 5. London, Taylor and Francis. p. 249-436. [1879-1885]

Blackwelder, R.E. 1946. Checklist of the coleopterous insects of Mexico, Central America, the West Indies and South America. Part 4. Bulletin of the United States National Museum, 185: 551-763.

Gemminger, M. 1873. Cerambycidae (Lamiini). In: Gemminger, M. \& Harold, E. (Eds.). Catalogus coleopterorum hucusque descriptorum synonymicus et systematicus. V. 10. Munich, Gummi. p. 2989-3216.

Gilmour, E.F. 1965. Catalogue des Lamiaires du Monde (Col., Cerambycidae). Museum G. Frey, Tutzing bei München, 8: 559-655.

Monné, M.A. 1985. Sinopse do gênero Nyssodrysternum Gilmour, 1960, com nota sobre 0 "complexo Nyssodrys" (Coleoptera, Cerambycidae, Lamiinae, Acanthocinini). Revista Brasileira de Entomologia, 29(3-4): 535-548.

Monné, M.A. 1995. Catalogue of the Cerambycidae (Coleoptera) of the Western Hemisphere. Part XVIII. Subfamily Lamiinae: Tribe Acanthocinini. São Paulo, Sociedade Brasileira de Entomologia. 196p.

Monné, M.A. 2005. Catalogue of the Cerambycidae (Coleoptera) of the Neotropical Region. Part II. Subfamily Lamiinae. Zootaxa, 1023: 1-759.

Monné, M.A. 2021. Catalogue of the Cerambycidae (Coleoptera) of the Neotropical region. Part II. Subfamily Lamiinae. Available: https:// cerambycids.com/default.asp?action=show catalog. Access:02/04/2021.

Monné, M.A. \& Giesbert, E.F. 1994. Checklist of the Cerambycidae and Disteniidae (Coleoptera) of the Western Hemisphere. Burbank, Wolfsgarden Books. 409p.

Monné, M.A.; Santos-Silva, A. \& Monné, M.L. 2020. Key to South American genera of Acanthocinini (Coleoptera, Cerambycidae, Lamiinae) without erect setae on elytra; synonymies, transferences, revalidation, and notes on genera with erect setae on elytra. Zootaxa, 4863(1): 1-65.

Morvan, 0. \& Roguet, J-P. 2013. Inventaire des Cerambycidae de Guyane (Coleoptera). Supplement au Bulletin de liaison d'ACOREP France "Le Coleopteriste", 7: 3-44.

$\emptyset$ degaard, F. 2004. Species richness of phytophagous beetles in the tropical tree Brosimum utile (Moraceae); the effects of sampling strategy and the problems of tourists. Ecological Entomology, 29: 76-88.

Wappes, J.E., Morris, R.F., Nearns, E.H. \& Thomas, M.C. 2006. Preliminary list of Bolivian Cerambycidae (Coleoptera). Insecta Mundi, 20(1-2): 1-45. 